\title{
Alternative Road Vehicles, Electric Rail Systems, Short Flights: An Environmental Comparison
}

\author{
Julien Matheys*, Tim Festraets*, Jean-Marc Timmermans*, \\ Nele Sergeant*, and Joeri Van Mierlo*
}

In a context of global warming, the energy-efficiency topic has never been as hot as it is now, especially as far as transportation is concerned. Road and rail transportation are both included in what currently is the main attempt to tackle climate change on a worldwide scale: the Kyoto protocol. The achievement of the objectives put forward in this international agreement might be reached thanks to the high energy efficiency of electric drives for both road and rail transportation. International aviation emissions however, have not been included in the targets of the Kyoto protocol. Nevertheless, as in some cases aviation competes with surface transport, the energy efficiencies and/or climate impacts of different alternative drives or transport modes for surface transport should be compared to (mainly short-haul and very short-haul) aviation.

In this paper the environmental relevance of a planned prohibition of very short-haul flights in Belgium is assessed. This is done through the case-study of an abandoned project to operate a 737-400 flight between the Belgian cities of Liège and Charleroi ( $75 \mathrm{~km}$ distance), before taking off to Casablanca, Morocco (approximately $2100 \mathrm{~km}$ from Charleroi). The emissions due to the Liège-Charleroi leg of the flight are compared to alternatives for passenger transport, such as road transport and rail transport. Concerning road transport, different alternatives (conventional, CNG, hybrid, electric drive cars and buses) will be considered. After an assessment of the different transfer possibilities, an evaluation of the most climate-friendly and energy efficient scenarios is performed. Moreover an estimation of the yearly CO2-equivalent savings is carried out.

Keywords: Electric Vehicle, Fast Market Entry, Myers Motors, Environmental Effectiveness

\section{INTRODUCTION}

Transportation is one of the main sectors for which a great effort is required if the international community wants to reach the commitments made in the Kyoto protocol. Road and rail transportation are both included in what currently is the main attempt to tackle climate change on a worldwide scale. The achievement of the objectives put forward in this international agreement might be reached thanks to the high energy efficiency of electric drives for both road and rail transportation. However, the Kyoto protocol targets only include emissions originating from domestic flights and don't include international aviation emissions. The Kyoto protocol requires that Annex I countries: "...pursue limitation or reduction of [GHG emissions from aviation], working through the International Civil Aviation Organization (ICAO)...”. In 2001, the ICAO endorsed the development of open emissions trading for international aviation. The extension of the European Union's Emission Trading Scheme (EU-ETS) is being evaluated and developed right now by the European

*Vrije Universiteit Brussel, ETEC, Pleinlaan 2, B-1050 Brussel
Union under great international attention.

The intensity of air travel has never been as high as it currently is [1]. Providing unseen exchanging possibilities and comfort to travelling people around the world, the current growth in international air traffic also threatens the potential beneficial achievements of some efforts made in other sectors towards reducing their contribution to global warming and other environmental impacts.

Alternative vehicles, such as battery, hybrid and fuel cell electric cars, as well as rail transportation systems are often praised for their environmental performances as compared to conventional gasoline or diesel vehicles. The energy efficiency of electric drives is high and the possibility of regenerative braking makes them the most energy efficient transport mode over land [2]. Many studies compare the energy efficiencies and/or climate impacts of different alternative drives or transport modes for surface transport. However, in some cases, these transport modes compete with, and therefore should be compared to aviation. This is mainly the case for the so-called very short haul flights (less than one 
hour of flying).

In this context and with the aim to improve the energy efficiency and the climate friendliness of its transport system, the Belgian government is evaluating the possibility to prohibit the very short haul flights (of less than $150 \mathrm{~km} / \sim 90$ miles) within the country. The main operation concerned by this prohibition was a planned $75 \mathrm{~km}$ Boeing 737-400 flight between the Brussels South Charleroi Airport (CRL) and the Liège Bierset Airport (LGG) to group passengers before leaving to Morocco, Casablanca Airport (CMN). This planned leg of the flight has been cancelled in the meantime.

In this paper, the environmental relevance of this measure is evaluated by comparing the greenhouse gas emissions due to this type of very short flights with other alternatives for passenger transfer (surface transport) between both airports and cities. As aviation induces some other climate-related effects besides $\mathrm{CO}_{2}$ emissions [3], a short overview of the other climate influencing aspects $\left(\mathrm{NO}_{\mathrm{x}}\right.$ emissions, stratospheric cloud formation, contrail formation, etc.) is provided. However, the focus of the case-study will be on $\mathrm{CO}_{2}$ emissions.

In this paper, special attention will be paid to the energy efficiencies of the different transport modes for these specific short distances. In this context, the

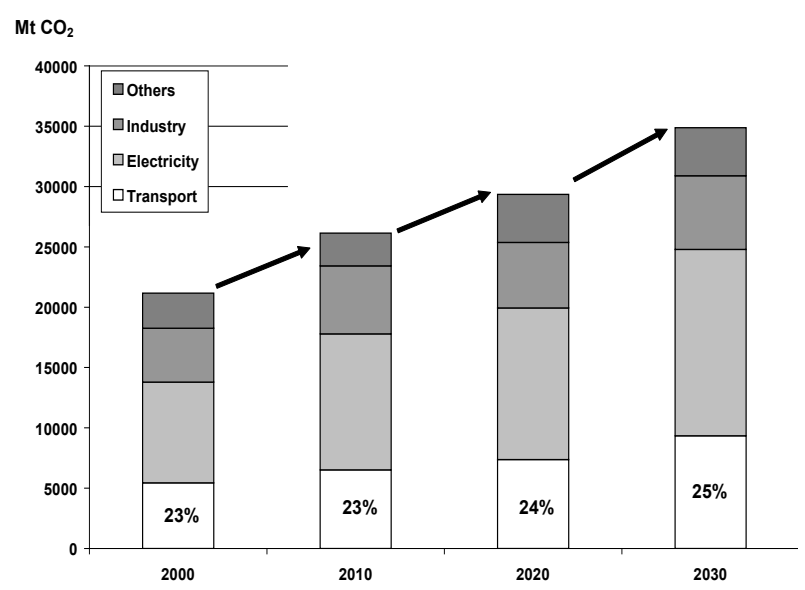

Figure 1: Prediction of the worldwide $\mathrm{CO}_{2}$ emissions per sector (adapted from [6])

climate impact of the well-to-tank chain will be taken into account. So in the case of the electric drives, the electricity production mix will be analysed as well.

After modelling the different scenarios and taking the technical feasibility into account, the most climatefriendly and energy efficient scenarios will be selected and an evaluation of the yearly $\mathrm{CO}_{2}$-equivalent savings will be performed.

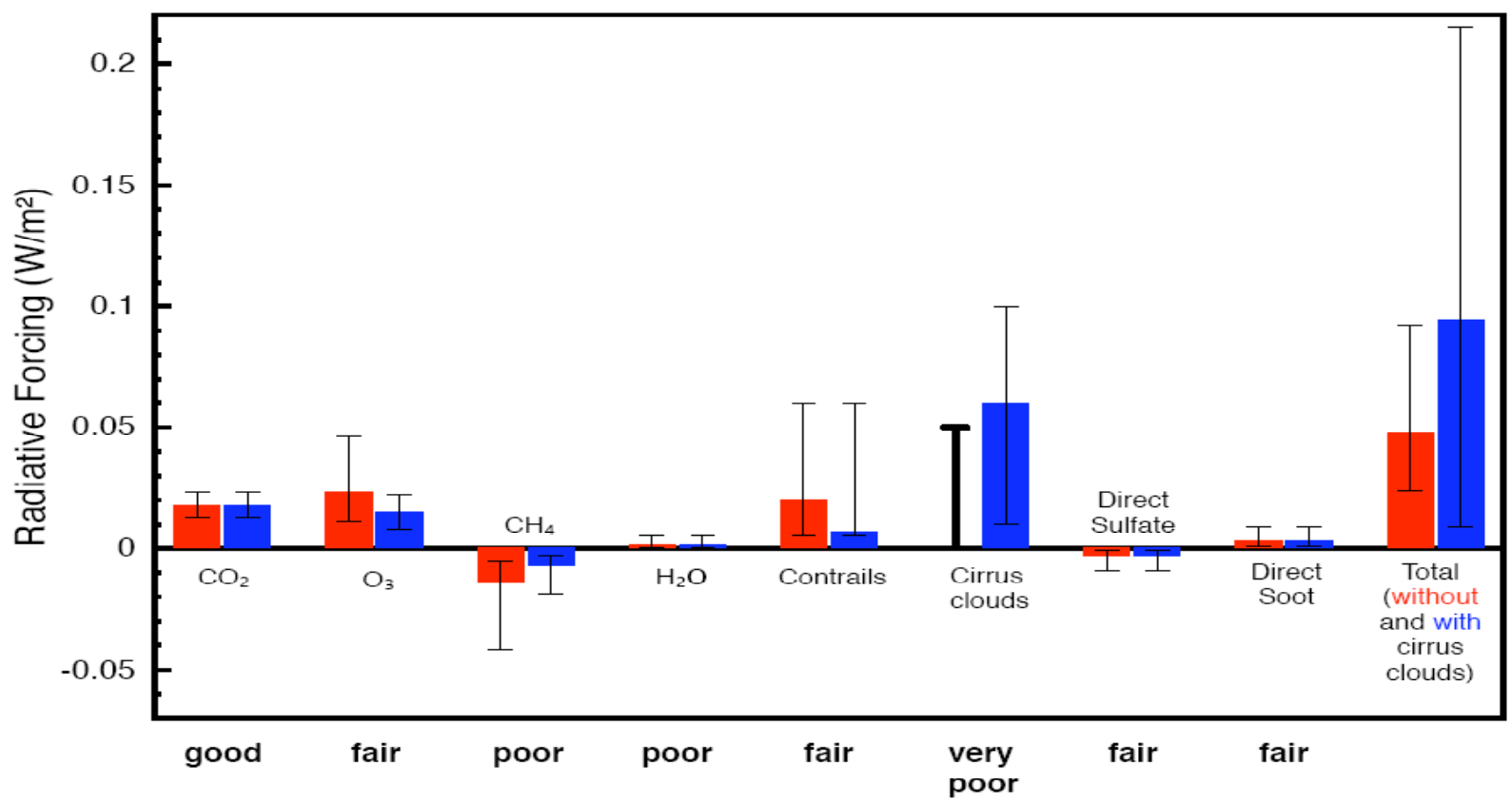

Figure 2: Overview of the different ways in which air transport influences radiative forcing ([9] adapted from [10]) 


\section{AVIATION AND CLIMATE}

Anthropogenic radiative forcing (or global warming caused by human activities) is mainly caused by $\mathrm{CO}_{2}$ emissions [4]. Therefore, although some integrated approach over the different greenhouse gases is necessary, it seems sensible to pay special attention to this greenhouse gas. When looking at the different sectors it seems clear that a significant part of the worldwide $\mathrm{CO}_{2}$ emissions are currently due to transport. Moreover, the share of transport in an expanding total of $\mathrm{CO}_{2}$ emissions worldwide is even expected to grow in the future (Figure 1). This is one of the main reasons to perform an analysis of the transport sector and to think about how to improve the efficiency and climatefriendliness of this sector. Moreover it should be noted that currently there is no legislation at European Union level to regulate $\mathrm{CO}_{2}$ emissions from aviation. However, the European Commission is planning to take action in the very near future by bringing the aviation sector within the scope of the European emission trading scheme, the EU-ETS [5].

As mentioned before, on a worldwide scale, $\mathrm{CO}_{2}$ is by far the emission that impacts climate in the strongest way. Due to the very long residence time of $\mathrm{CO}_{2}$ in the atmosphere, aircraft $\mathrm{CO}_{2}$ emissions get well mixed with the $\mathrm{CO}_{2}$ emissions of other anthropogenic sources. Regarding other (non- $\mathrm{CO}_{2}$ ) emissions, aviation presents the specific characteristic of emitting a large fraction of its emissions in the stratosphere. Due to the altitude where these emissions take place, they influence climate in a different way as compared to when they would occur on ground level. Subsonic aircraft (virtually all passenger aircraft) tend to decrease the lifetime of $\mathrm{CH}_{4}$ in the atmosphere due to their $\mathrm{NO}_{\mathrm{x}}$ emissions. On the other hand, ozone is a very short-lived greenhouse gas. Its production is increased by the emissions of $\mathrm{NO}_{\mathrm{x}}$ and thus results in a heating effect. Moreover aviation is also responsible for condensation trails (contrails) and possibly also for the formation of cirrus clouds. Figure 2 gives an overview of the different impacts of aviation on climate. The total impact of aviation on the climate is believed to be two- to five-fold that of $\mathrm{CO}_{2}$ alone [7],[8]. The scientific certainties of the different kinds of impacts are provided below the horizontal axis. Radiative forcing from air traffic as estimated by the IPCC [3] is shown in red, while a recently revised estimation for the same fleet is shown in blue (TRADEOFF project).

\section{DEFINITION OF THE SCENARIOS}

The CRL and LGG airports are located about 75 $\mathrm{km} / \sim 45$ miles from each other and are directly connected through a highway $(82 \mathrm{~km})$ (Figure 3). The cities of Liège and Charleroi are directly linked by intercity trains (82 km track). Currently, none of both airports

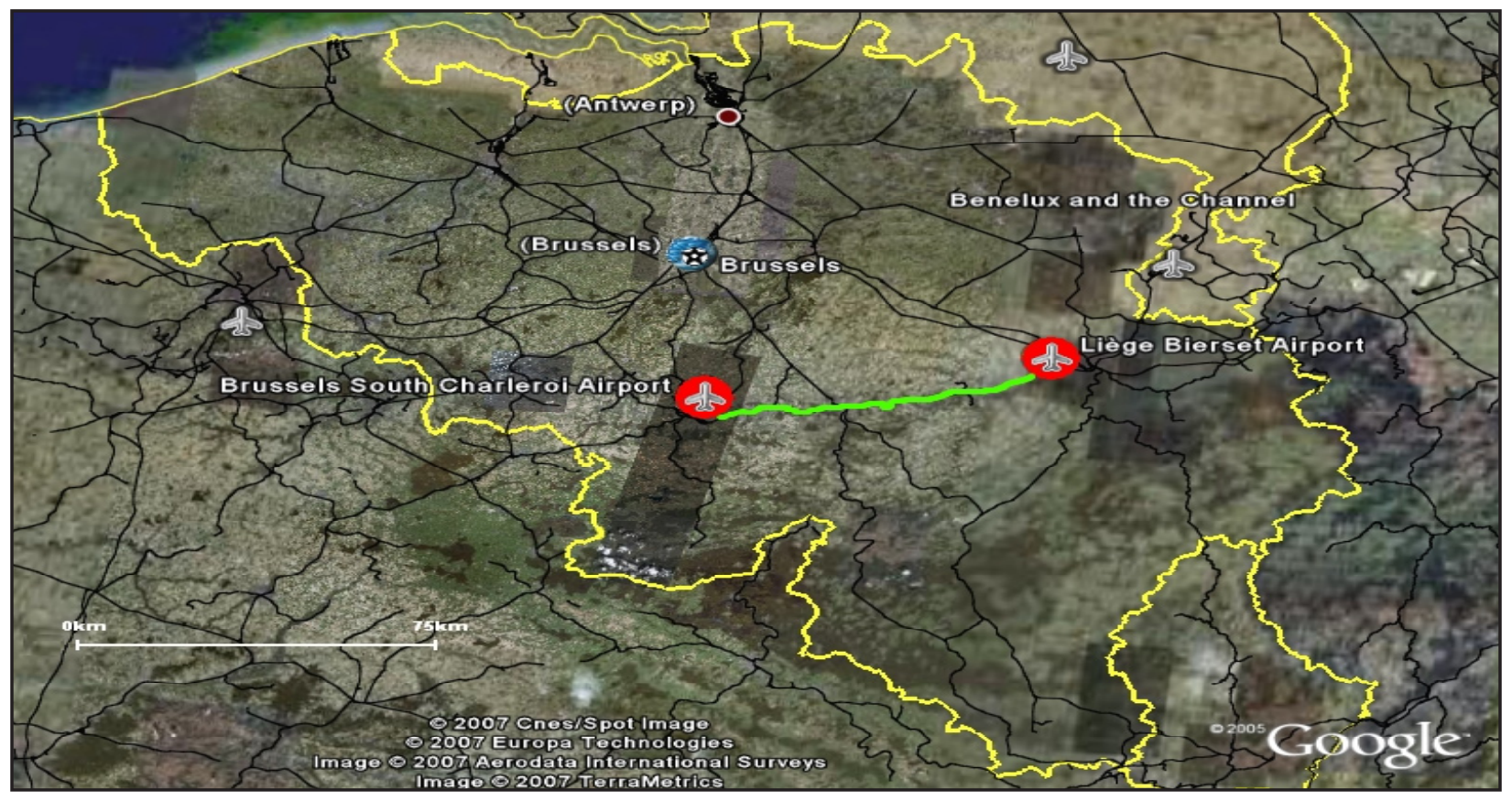

Figure 3: Map of Belgium indicating the location of the CRL and LGG airports, as well as the rail track (in green) currently connecting the city centres of Charleroi and Liège 


\begin{tabular}{|l|l|l|l|l|}
\hline Scenario & Distance to be covered & Passengers/vehicle & Vehicles needed & Consumption \\
\hline Reference (Aircraft) & $75 \mathrm{~km}$ & 88 & 1 & $1150 \mathrm{~kg} /$ CRL-LGG \\
\hline Gasoline & $82 \mathrm{~km}$ & 1,37 & 64 & $6,71 / 100 \mathrm{~km}$ \\
\hline Diesel & $82 \mathrm{~km}$ & 1,37 & 64 & $5,61 / 100 \mathrm{~km}$ \\
\hline Hybrid car (Gasoline) & $82 \mathrm{~km}$ & 1,37 & 64 & $4,31 / 100 \mathrm{~km}$ \\
\hline Battery electric car & $82 \mathrm{~km}$ & 1,37 & 64 & $0,2 \mathrm{kWh} / 100 \mathrm{~km}$ \\
\hline Car-pooling (Gasoline) & $82 \mathrm{~km}$ & 4 & 22 & $6,71 / 100 \mathrm{~km}$ \\
\hline Diesel bus & $82 \mathrm{~km}$ & 44 & 2 & $251 / 100 \mathrm{~km}$ \\
\hline Hybrid Diesel bus & $82 \mathrm{~km}$ & 44 & 2 & $201 / 100 \mathrm{~km}$ \\
\hline Electric bus & $82 \mathrm{~km}$ & 15 & 6 & $0,8 \mathrm{kWh} / \mathrm{km}$ \\
\hline CNG bus & $82 \mathrm{~km}$ & 44 & 2 & $40 \mathrm{Nm} / 100 \mathrm{~km}$ \\
\hline Electric train & $82 \mathrm{~km}$ & 88 & 1 & $0,08-0,34 \mathrm{kWh} / \mathrm{pkm}$ \\
\hline
\end{tabular}

Table 1: Overview of the assumptions for the different scenarios

\begin{tabular}{|l|c|c|c|c|c|c|}
\hline Scenario & $\begin{array}{c}\text { Total fuel/electricity } \\
\text { consumption }\end{array}$ & $\begin{array}{c}\mathrm{CO}_{2} \text { emissions per liter, per } \\
\mathrm{Nm}^{3} \text { or per kWh }\end{array}$ & \multicolumn{3}{|c|}{ Total $\mathrm{CO}_{2}$ emissions (kg) } \\
\hline & & Indirect & Direct & Indirect & Direct & Total \\
\hline Reference (Aircraft) & $1150 \mathrm{~kg}$ & $276 \mathrm{~g} / \mathrm{kg}$ & $3150 \mathrm{~g} / \mathrm{kg}$ & 317 & 3623 & 3940 \\
\hline Gasoline & 351,61 & $297 \mathrm{~g} / 1$ & $2212 \mathrm{~g} / 1$ & 104 & 778 & 882 \\
\hline Diesel & 285,71 & $250 \mathrm{~g} / 1$ & $2697 \mathrm{~g} / 1$ & 71 & 771 & 841 \\
\hline Hybrid car (Gasoline) & 225,61 & $297 \mathrm{~g} / 1$ & $2212 \mathrm{~g} / 1$ & 67 & 499 & 566 \\
\hline Car-pooling (Gasoline) & 120,91 & $297 \mathrm{~g} / 1$ & $2212 \mathrm{~g} / 1$ & 36 & 267 & 303 \\
\hline Battery electric car & $1049,6 \mathrm{kWh}$ & $273 \mathrm{~g} / \mathrm{kWh}$ & 0 & 287 & 0 & 287 \\
\hline Electric train & $574,3-2453,4 \mathrm{kWh}$ & $273 \mathrm{~g} / \mathrm{kWh}^{\prime}$ & 0 & $157-670$ & 0 & $157-670$ \\
\hline CNG bus & $65,6 \mathrm{Nm}^{3}$ & $138 \mathrm{~g} / \mathrm{Nm}^{3}$ & $2048 \mathrm{~g} / \mathrm{Nm}^{3}$ & 9 & 134 & 142 \\
\hline Diesel bus & 41,01 & $250 \mathrm{~g} / 1$ & $2697 \mathrm{~g} / 1$ & 10 & 111 & 121 \\
\hline Hybrid Diesel bus & 32,81 & $250 \mathrm{~g} / 1$ & $2697 \mathrm{~g} / 1$ & 8 & 88 & 97 \\
\hline Electric bus & $343,6 \mathrm{kWh}$ & $273 \mathrm{~g} / \mathrm{kWh}$ & 0 & 94 & 0 & 94 \\
\hline
\end{tabular}

Table 2: Overview of the overall energy consumption and $\mathrm{CO} 2$ emissions for the different scenarios

is connected directly by rail, however both airports are located close to the existing railway track connecting both city centres $(2 \mathrm{~km}$ for the CRL airport and $3 \mathrm{~km}$ for the LGG airport). This makes the addition of some airport railway stations an interesting option for the future (implicitly increasing the accessibility of both airports). Alternative connections thus include: road transport (using different transport modes, such as conventional and electric drives for cars and buses) and rail transport.

\section{COMPARISON OF THE EFFECTIVENESS OF THE DIFFERENT SCENARIOS}

Now the scenarios have been defined, the calculation of the $\mathrm{CO}_{2}$ emissions has to be performed. The fuel or electricity needed for the different scenarios, as well as the according $\mathrm{CO}_{2}$ emissions are presented in Table 2. The total fuel consumption is obtained by multiplying the covered distance by the consumption and the number of vehicles needed to transfer the passengers. The $\mathrm{CO}_{2}$ emissions presented in Table 2 are well-towheel emissions. This means they include direct and indirect $\mathrm{CO}_{2}$ emissions.
Table 2 and Figure 4 show that the scenarios using buses are causing the lowest amounts of $\mathrm{CO}_{2}$ emissions. These scenarios are followed by the electric train battery electric vehicle and carpooling scenarios. In turn these are followed by the other personal vehicle scenarios and finally by the reference scenario (very short-haul flight). Currently six weekly return flights are operated from the Charleroi airport to Casablanca. If it is assumed every flight would make a stop-over, six weekly CRLLGG flights, as well as six weekly LGG-CRL flights would be operated, resulting in 12 flights/week * 52 weeks/year * $3940 \mathrm{~kg}$ of $\mathrm{CO}_{2} /$ flight $=2.458 .560 \mathrm{~kg}$ of $\mathrm{CO}_{2}$ a year. Replacing these flights by the transport mode with the lowest $\mathrm{CO}_{2}$ emissions (electric buses) would result in 12 trips/week * 52 weeks/year * $94 \mathrm{~kg}$ $\mathrm{CO}_{2} /$ trip $=58.656 \mathrm{~kg} \mathrm{CO}$ a year. In other words, the electric bus scenario would save $2.399 .904 \mathrm{~kg}$ or 2.400 tonnes of $\mathrm{CO}_{2}$ emissions on a yearly basis.

\section{CONCLUSIONS}

When comparing the different performances concerning $\mathrm{CO}_{2}$ emissions, it clearly appears that for such a short distance, the most climate-friendly way to 


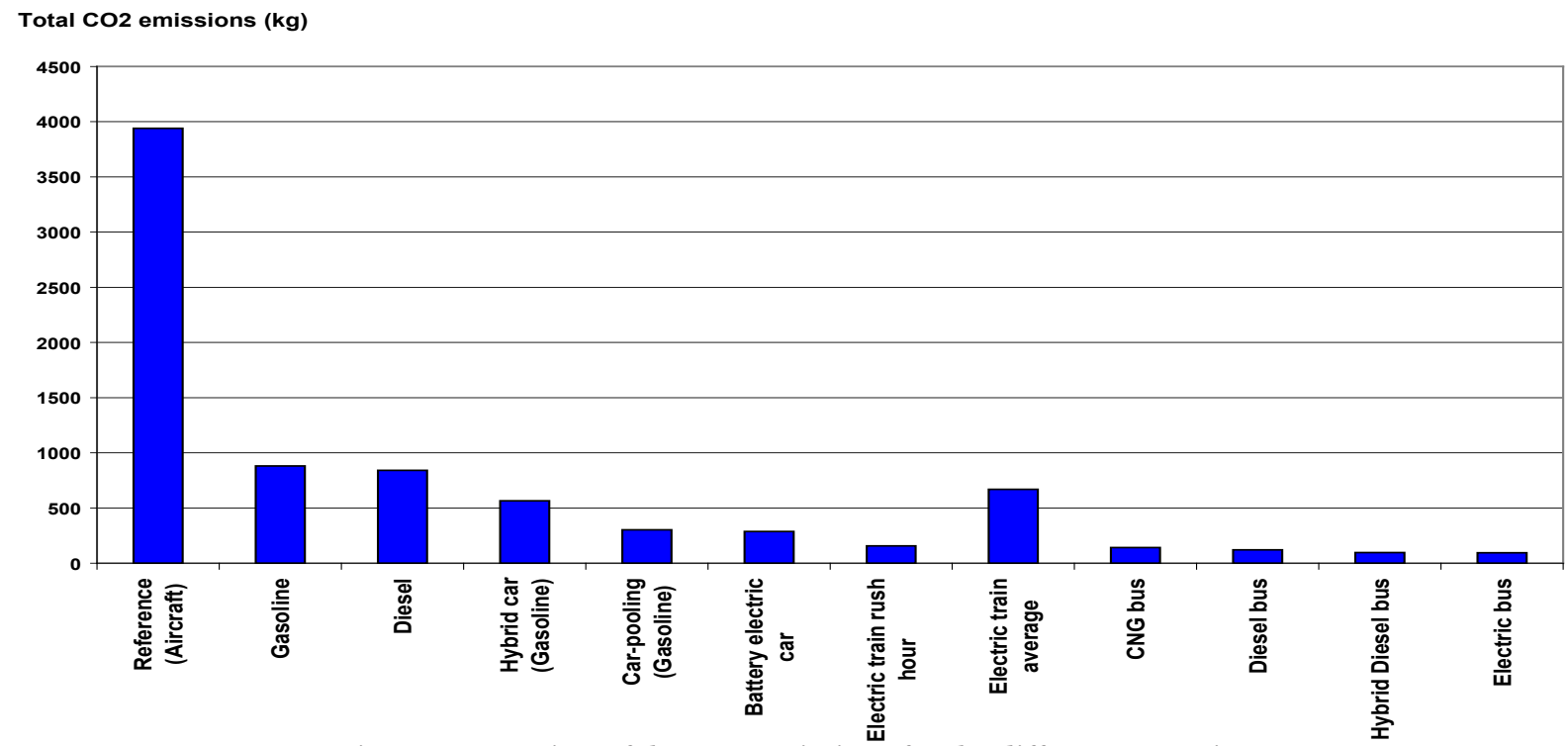

Figure 4: Overview of the $\mathrm{CO} 2$ emissions for the different scenarios

transfer the passengers from one airport to the other is by surface transportation. Amongst the different options for surface transport electric buses appear to be resulting in the lowest quantity of emissions. In general, as can be seen from the performance of buses, trains and carpooling, it can be concluded that grouping passengers before transferring them over land is the best way to minimize $\mathrm{CO}_{2}$ emissions. Moreover, within the different scenarios it appears that using electric drives (hybrid and battery electric vehicle or bus, electric train) for passenger transport strongly reduces well-to-wheel $\mathrm{CO}_{2}$ emissions.

The difference between the scenarios resulting in the highest and the lowest $\mathrm{CO}_{2}$ emissions is equivalent with a saving of 2.400 tonnes of $\mathrm{CO}_{2}$ emissions on a yearly basis.

It should be noted that the conclusions of this paper give an indication of the climate-change performance of the different transport modes for this specific veryshort distance transfer of passengers. Consequently another analysis should be performed before drawing any conclusion for long-haul flights. In the specific case of long-haul flights the assessed transport modes should take the feasibility (duration of the trip, travelling overseas, etc.) of the transfer into account as well.

The assessment presented here is based on the $\mathrm{CO}_{2}$ emissions of the different transport modes and although $\mathrm{CO}_{2}$ is the predominant greenhouse gas, for completeness, the other greenhouse gases could be included in the future.

\section{REFERENCES}

[1] Airbus (2004). Global Market Forecast 2004-2023. p.81.

[2] Van Mierlo J., Maggetto G., Lataire Ph. (2006). Which energy source for road transport in the future? A comparison of battery, hybrid and fuel cell vehicles. Energy conversion and management 47, 2748-2760.

[3] IPCC (1999). Penner J. E., Lister D. H.,. Griggs D. J., Dokken D. J. \& McFarland M., editors. Aviation and the global atmosphere. Cambridge University Press, Cambridge, UK and New York, USA, 1999.

[4] IPCC (2001) Climate Change 2001. Third assessment report UNEP International Panel on Climate Change.

[5] European Commission (2006) Proposal for a directive of the European Parliament and of the Council amending directive 2003/87/EC so as to include aviation activities in the scheme for greenhouse gas emissions allowance trading within the Community, Brussels, Belgium

[6] Morcheoine (2005). Quelles perspectives de réductions de $\mathrm{CO}_{2}$ dans le secteur des transports? (route et aviation. Colloque international - Réduction des émissions et stockage géologique du $\mathrm{CO}_{2}, 15-16$ Septembre 2005, Paris.

[7] Can Europe (2006). Clearing the air: the myth and reality of aviation and climate change, Belgium, 46p

[8] Sausen R. et al (2005). Aviation radiative forcing in 2000: an update on IPCC (1999)

[9] FerroneA. (2006). Modeling of the Impact of Aviation on Climate Master Thesis, Institut d'Astronomie et de Géophysique Georges Lemaître, Université Catholique 
de Louvain.

[10] Schuman U. (2003). Aviation, Atmosphere and Climate - What has been learned, p. 349-355.

[11] CORINAIR Methodology available from the European Environmental Agency on: http://reports.eea. europa.eu/EMEPCORINAIR3/en/B851vs2.4.pdf

[12] Van Mierlo J., Matheys J., Timmermans J.-M., Govaerts L., Schrooten L., De Geest C. (2006). Milieurapport Vlaanderen 2006. Chapter 1: Transport pp 271.

[13] Matheys J., Timmermans J.-M., Van Mierlo J., Maggetto G. (2006). Environmental Assessment of the Past, Present and Future Urban Bus Fleets, the Advantages of Battery, Trolley and Hybrid Electric Busses. Proceedings of EVS-22: The 22nd International Battery, Hybrid and Fuel Cell Electric Vehicle Symposium, 23-28 October 2006, Yokohama, Japan.

\section{AUTHORS}

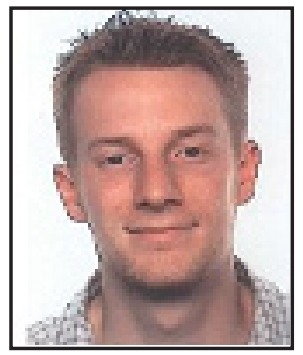

Julien Matheys graduated in 2003 as a Bio-engineer in Biotechnology from the Vrije Universiteit Brussel and obtained a postgraduate degree in Sustainable Development and Human Ecology at the same University in 2004. As a research assistant at ETEC, he was involved in an EU project (SUBAT), concerning LCA of batteries. In 2005 he worked mainly on the Ecoscore for buses and passenger cars. Since 2006 Julien Matheys has been involved in the ABC Impacts project analysing the inclusion of air transport into European and international climate policy. julien.matheys@vub. ac.be.

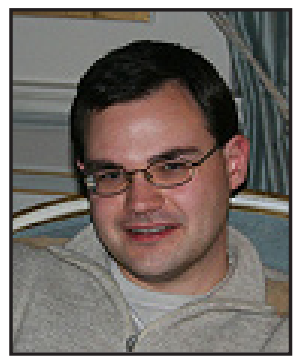

Tim Festraets graduated in 2003 with a Master's in Applied Economics from the Vrije Universiteit Brussel. Before joining the research team MOSI-T of the Vrije Universiteit Brussel in 2006 he worked as a consultant and for two and a half years as project coordinator mobility plans with the department of roads and infrastructure of the province Vlaams-Brabant. At the moment he is part of the ABC Impacts project where he is responsible for the economic analysis of bringing the Belgian aviation business into the European and international climate policy.

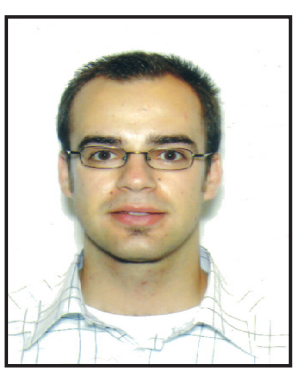

Jean-Marc Timmermans graduated in 2003 as an Electromechanical Engineer from the Vrije Universiteit Brussel. His Master's thesis dealt with the development of a test bench for electric bicycles. As an academic assistant, he is involved in projects about the evaluation of the environmental impact of conventional and alternative vehicles and he is also involved in the development of electric postal bikes. Further research goes to the evaluation of hybrid electric drive trains for road vehicles.

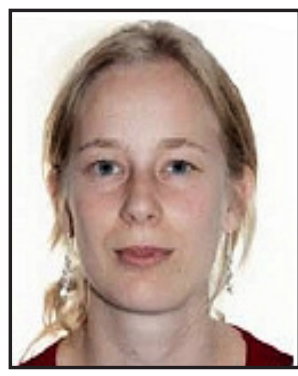

NeleSergeantreceived the degree of Bio-engineer in biotechnology at the Vrije Universiteit Brussel in 2003, after which she specialized in environmental science and technology and the Katholieke Universiteit Leuven. She started working as a Ph.D. student at the Electrotechnical engineering department (ETEC) of the Vrije Universiteit Brussel on the Ecoscore methodology and the development of an LCA for conventional and alternative vehicles.

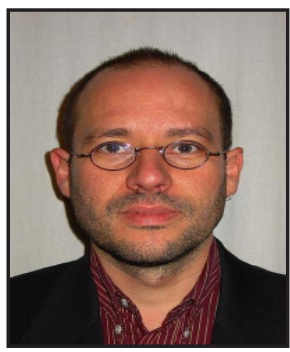

Joeri Van Mierlo obtained his Ph.D. in Engineering Sciences from the Vrije Universiteit Brussel. Joeri is now a full-time lecturer at this university, where he leads the ETEC research team on transport technology. His research interests include vehicle and drive train simulation, as well as the environmental impact of transportation. 